University of Nebraska - Lincoln

DigitalCommons@University of Nebraska - Lincoln

Other Publications in Zoonotics and Wildlife

Disease

Wildlife Disease and Zoonotics

1998

Serologic Evidence of Infection with Ehrlichia spp. in Wild Rodents (Muridae: Sigmodontinae) in the United States

\author{
William L. Nicholson \\ Centers for Disease Control and Prevention, Atlanta \\ Susie Muir \\ Centers for Disease Control and Prevention, Atlanta \\ John W. Sumner \\ Centers for Disease Control and Prevention, Atlanta \\ James E. Childs \\ Centers for Disease Control and Prevention, Atlanta, james.childs@yale.edu
}

Follow this and additional works at: https://digitalcommons.unl.edu/zoonoticspub

Part of the Veterinary Infectious Diseases Commons

Nicholson, William L.; Muir, Susie; Sumner, John W.; and Childs, James E., "Serologic Evidence of Infection with Ehrlichia spp. in Wild Rodents (Muridae: Sigmodontinae) in the United States" (1998). Other Publications in Zoonotics and Wildlife Disease. 68.

https://digitalcommons.unl.edu/zoonoticspub/68

This Article is brought to you for free and open access by the Wildlife Disease and Zoonotics at DigitalCommons@University of Nebraska - Lincoln. It has been accepted for inclusion in Other Publications in Zoonotics and Wildlife Disease by an authorized administrator of DigitalCommons@University of Nebraska - Lincoln. 


\title{
Serologic Evidence of Infection with Ehrlichia spp. in Wild Rodents (Muridae: Sigmodontinae) in the United States
}

\author{
WILLIAM L. NICHOLSON, ${ }^{1,2 *}$ SUSIE MUIR, ${ }^{1}$ JOHN W. SUMNER, ${ }^{1}$ AND JAMES E. CHILDS ${ }^{1}$ \\ Viral and Rickettsial Zoonoses Branch, Division of Viral and Rickettsial Diseases, National Center for \\ Infectious Diseases, Centers for Disease Control and Prevention, Atlanta, Georgia 30333, ${ }^{1}$ \\ and Department of Molecular Microbiology and Immunology, Johns \\ Hopkins University, Baltimore, Maryland $21205^{2}$
}

Received 2 June 1997/Returned for modification 14 July 1997/Accepted 14 November 1997

\begin{abstract}
Rodent (Muridae: Sigmodontinae) blood and sera collected from 14 states were tested for seroreactivity to a cultured isolate of the human granulocytic ehrlichiosis (HGE) agent by using an indirect immunofluorescence assay. Of the 1,240 samples tested, $136(11 \%)$ were found to be reactive at titers of $\geq 32$. Rodents with HGE agent-specific antibodies were found in New York (23\% of 491 samples; geometric mean endpoint titer [GMT] = 441), Connecticut (11\% of 100 samples; GMT = 481), California (9\% of 32 samples; GMT $=323)$, Colorado ( $2 \%$ of 212 samples; GMT $=256)$, Florida $(7 \%$ of 27 samples; GMT $=362)$, Maryland $(7 \%$ of 15 samples; titer = 64), New Jersey (4\% of 76 samples; titer = 256), and Wisconsin (13\% of 8 samples; titer = 128). Samples from Georgia $(n=16)$, Illinois $(n=27)$, Nevada $(n=27)$, North Carolina $(n=52)$, Ohio $(n=$ $57)$, and Utah $(n=100)$ were not reactive. The earliest seroreactive sample was from a Peromyscus leucopus mouse collected in June 1986 in Connecticut, and the majority of the seroreactive samples $(68 \%)$ were from this species. Samples from other Peromyscus species ( $P$. boylii, $P$. maniculatus, and $P$. gossypinus) were also found to be reactive, with a GMT for the genus of 410 . Several species of Neotoma woodrats ( $N$. fuscipes, $N$. lepida, $N$. albigula, and $N$. mexicana) from California and Colorado had antibodies that reacted with the HGE agent (genus GMT = 194), suggesting that enzootic cycles of Ehrlichia spp. exist outside of the areas of confirmed human disease. Attempts to amplify and detect ehrlichial DNA from the limited tissues available $(n=40$ animals) were unsuccessful. Further studies are needed to determine the identity of the organisms inducing antibody production in these rodent species and to elucidate the epidemiology and public health importance of these agents.
\end{abstract}

Human ehrlichiosis may result from infection by at least four ehrlichial agents. Ehrlichia sennetsu is not known to occur in the United States (13), and an ehrlichial agent identified as Ehrlichia canis may cause subclinical infections in humans in Venezuela (24). Two forms of human ehrlichiosis have been recognized in the United States during the last decade. The first human case, initially thought to be due to infection with E. canis, was recognized in the United States in 1986, and more than 400 human cases due to Ehrlichia chaffeensis have since been reported (8). Human granulocytic ehrlichiosis (HGE) was first described in 1994 on the basis of findings from a series of patients observed in Wisconsin and Minnesota from 1990 to 1993 (9). Since then, about 170 cases have been diagnosed in patients in Arkansas, California, Connecticut, Florida, Maryland, Massachusetts, Minnesota, New York, Pennsylvania, Rhode Island, and Wisconsin (29). Serologic evidence for infection by the HGE agent or by a closely related agent has been reported from Norway (3), Switzerland (5), and the United Kingdom (26).

The agent or agents responsible for these HGE cases have not been fully characterized. Ehrlichia equi and other members of the Ehrlichia phagocytophila genogroup are very closely related, if not conspecific, organisms. Serologic (12), animal transfer (18), and genetic (9) evidence indicates that these taxa represent a single species. Much of the genetic similarity is

* Corresponding author. Mailing address: Viral and Rickettsial Zoonoses Branch, Centers for Disease Control and Prevention, 1600 Clifton Rd., Mailstop G-13, Atlanta, GA 30333. Phone: (404) 6391075. Fax: (404) 639-4436. E-mail: wan6@cdc.gov. based on sequence analyses of the 16S rRNA gene. Further analysis of additional gene sequences, complemented by animal infection and antigenic analyses, is needed to clarify the taxonomic positions of these agents.

Little information is available concerning the natural history of the HGE agent and similar ehrlichial organisms. The only known maintenance or natural hosts of other ehrlichiae are wild and domestic mammals. However, as most ehrlichiae have been described from observations of clinically ill domestic hosts, the natural reservoir hosts of the agents remain uncertain. Epidemiologic evidence from the initial HGE case series suggested that blacklegged ticks (Ixodes scapularis) or American dog ticks (Dermacentor variabilis) might be the vector species responsible for transmission $(2,29)$. Subsequently, DNA of the HGE agent was amplified from I. scapularis by PCR assays (23) and from laboratory-reared ticks that fed upon wild white-footed mice (Peromyscus leucopus) caught in an area where HGE is endemic (27). Infected Peromyscus mice have been identified within the geographic range of the northern subspecies, $P$. leucopus noveboracensis, thus suggesting that this subspecies may serve as the primary reservoir host in the northeastern United States. The identification of a putative vertebrate reservoir and a tick vector for the HGE agent that are identical to those involved in the maintenance and transmission of Borrelia burgdorferi has led to the expectation that the epidemiology of HGE may be similar to that of Lyme borreliosis.

Recent success in the in vitro propagation of E. equi and the HGE agent has led to the development of serologic assays (14, $21,22)$ which provide rapid and inexpensive ways to identify 
antibodies reactive to the $\mathrm{HGE}$ agent in humans and wild or domestic animals that might serve as potential reservoir hosts. Identification of the reservoirs of these organisms will provide insight into the ecology and natural transmission cycles of ehrlichiae and thereby facilitate the development of preventative measures to reduce human and animal exposure to these potentially life-threatening pathogens. In this study, we tested samples from sigmodontine rodents (Peromyscus spp. and Neotoma spp.) collected from several areas of the United States for antibodies reactive with the HGE agent.

\section{MATERIALS AND METHODS}

Samples. Four geographic regions in the United States were selected for serologic testing based on the hypothesis that the seroprevalence in the rodents would be associated with the estimated relative abundances of the expected vector (I. scapularis) and the expected rodent reservoir host (P. leucopus noveboracensis) of the HGE agent. Available samples from states within these regions were categorized as (i) areas where both the expected host and the tick were common (Connecticut, Maryland, New Jersey, New York, and Wisconsin), (ii) areas where both the expected host and tick were absent (California, Colorado, Nevada, and Utah), (iii) areas where the reservoir host was common and the tick was uncommon (Ohio and Illinois), and (iv) areas where the tick was common but the rodent host was uncommon or absent (Georgia, Florida, and North Carolina). Samples were made available through the archival serum bank of the Special Pathogens Branch of the Centers for Disease Control and Prevention and from several additional donors. Rodent samples collected over the period from 1986 to 1996 were provided to us from the following 14 states: California $(n=32)$, Colorado $(n=212)$, Connecticut $(n=100)$, Florida $(n=27)$, Georgia $(n=16)$, Illinois $(n=27)$, Maryland $(n=15)$, Nevada $(n=27)$, New Jersey $(n=$ $76)$, New York $(n=491)$, North Carolina $(n=52)$, Ohio $(n=57)$, Utah $(n=$ $100)$, and Wisconsin $(n=8)$. Most samples had been acquired during early studies of hantavirus pulmonary syndrome in the United States (10) and were stored frozen $\left(-70^{\circ} \mathrm{C}\right)$ as $1 / 32$ dilutions (one batch was stored as a $1 / 25$ dilution) of sera or whole blood in a diluent consisting of phosphate-buffered saline (PBS; $\mathrm{pH} 7.4$ ), $0.5 \%$ Tween $20,0.01 \%$ thimerosal, and 5\% skim milk. All tested samples were negative by enzyme-linked immunosorbent assay for the antibody to the hantavirus nucleocapsid antigen. Diluted samples were thawed overnight at $4^{\circ} \mathrm{C}$ and then mixed. The milk solids were allowed to settle, and an aliquot of the test samples was removed from the clarified specimen (initial studies had shown that excess milk solids would result in higher backgrounds).

IFA. Antigen for the indirect immunofluorescence assay (IFA) was kindly provided by Aquila Biopharmaceuticals (Worcester, Mass.) as human promyelocytes (HL-60) infected with a tick-derived isolate (USG3) of the HGE agent (11). The preparation of antigen slides and the assay details have been described previously (22). Briefly, the infected cells were allowed to adhere to the glass surface. Excess growth medium was removed, and slides were air dried. Antigen was fixed to the slides by immersion in acetone for $15 \mathrm{~min}$. Slides were stored dessicated at $-70^{\circ} \mathrm{C}$ until used.

Sera or plasma from 1,240 sigmodontine rodents representing five species in the genus Peromyscus and seven species in the genus Neotoma were tested for antibodies reactive with the cultured isolate of the HGE agent. All samples were initially screened at the lowest available common dilution (1/32). Twofold serial dilutions of reactive samples were made in diluent ( $0.01 \mathrm{M}$ PBS, $1 \%$ bovine serum albumin, $1 \%$ normal goat serum, $\mathrm{pH} 7.4)$, and an endpoint titer was determined. Positive control serum was obtained from a naturally infected $P$. leucopus mouse from Rhode Island (31), where infection was confirmed by PCR detection of HGE agent DNA. Negative control sera were collected from laboratory-reared P. leucopus mice (Peromyscus Genetic Stock Center, University of South Carolina, Columbia, S.C.). Positive, negative, and diluent controls were included on each slide. Optimal concentrations of reagents were determined by checkerboard titration of these controls. Slides were incubated at $37^{\circ} \mathrm{C}$ for $30 \mathrm{~min}$ and then washed three times for 5 min each with PBS. Fluorescein isothiocyanate-conjugated goat anti- $P$. leucopus immunoglobulin $\mathrm{G}$ (heavy plus light chains; Kirkegaard \& Perry Laboratories, Gaithersburg, Md.) diluted 1/25 was applied to each well, and the slides were incubated and washed as described above. During the next-to-last wash, Eriochrome Black T solution was added to counterstain the host cells. Coverslips were mounted with 0.3 M 1,4diazabicyclo[2.2.2] octane in 10\% PBS-90\% glycerol buffer, and the slides were examined with a UV epifluorescence microscope. Antibody titer was expressed as the reciprocal of the last dilution exhibiting definite ehrlichial fluorescence. The antibody titers were $\log _{2}$ transformed for comparisons of geometric mean endpoint titers (GMT).

Because we have seen reactivity to the USG3 antigen in sera from some humans with $E$. chaffeensis infection (22), all samples from mice collected in Florida $(n=27)$, Maryland $(n=15)$, New Jersey $(n=76)$, North Carolina $(n=$ $52)$, and Wisconsin ( $n=8)$ were tested against $E$. chaffeensis (Arkansas isolate) (1) antigen in a similar IFA. All other assay conditions and reagents were as described for the HGE testing.
PCR assays. Corresponding tissue samples were available for only 40 animals. Rodent liver $(n=9)$, lung $(n=3)$, spleen $(n=23)$, and whole-blood $(n=5)$ samples were processed for DNA extraction. Fifty microliters of whole blood or a small piece of tissue (ca. 5 by 5 by $5 \mathrm{~mm}$ ) was mixed with $300 \mu \mathrm{l}$ of $10 \mathrm{mM}$ Tris saline buffer containing $1 \%$ sodium dodecyl sulfate and $100 \mathrm{ng}$ of proteinase $\mathrm{K}$ per $\mathrm{ml}$. The suspension was incubated at $55^{\circ} \mathrm{C}$ for $2 \mathrm{~h}$ to digest proteins. The material was extracted three times with phenol-chloroform-isoamyl alcohol (25: 24:1), and the aqueous supernatant was added to Centricon-30 centrifugation units (Amicon, Beverly, Mass.). The DNA solution was washed three times with $10 \mathrm{mM}$ Tris saline buffer, and the final volume was adjusted to $100 \mu \mathrm{l}$. The extracted DNA was refrigerated (ca. 1 week) until it was tested in the PCR assay.

All PCR assays were prepared by using commercial amplification kits (GeneAmp; Roche Molecular Systems, Branchburg, N.J.). Ten microliters of DNA template was added to a buffer containing $100 \mathrm{mM}$ Tris- $\mathrm{HCl}$ (pH 8.3), $50 \mathrm{mM}$ $\mathrm{KCl}, 0.15 \mathrm{mM} \mathrm{MgCl}_{2}, 0.001 \%$ gelatin, a $200 \mu \mathrm{M}$ concentration of each dNTP, a $1 \mu \mathrm{M}$ concentration of each primer, and $2.5 \mathrm{U}$ of Taq polymerase. The primers used were GE9 and GE10 (9), modified to include restriction sites to facilitate cloning. The reaction mixture was overlaid with $50 \mu \mathrm{l}$ of mineral oil and cycled (Thermal Cycler; Perkin-Elmer Cetus, Norwalk, Conn.) for three preliminary cycles $\left(94^{\circ} \mathrm{C}\right.$ for $1 \mathrm{~min}, 55^{\circ} \mathrm{C}$ for $2 \mathrm{~min}$, and $72^{\circ} \mathrm{C}$ for $1.5 \mathrm{~min}$ ), followed by 37 amplification cycles $\left(88^{\circ} \mathrm{C}\right.$ for $1 \mathrm{~min}, 55^{\circ} \mathrm{C}$ for $2 \mathrm{~min}$, and $72^{\circ} \mathrm{C}$ for $1.5 \mathrm{~min}$ ) and then by an additional extension period of $5 \mathrm{~min}$ at $72^{\circ} \mathrm{C}$. A nested reaction was conducted for a total of 40 cycles with the universal 16S rRNA primers EC9 and EC12 (1) in the first round and primers GE9 and GE10 in the second round (40 cycles). During the first amplification, the annealing temperature of the reaction was lowered to $48^{\circ} \mathrm{C}$ and the extension temperature was lowered to $68^{\circ} \mathrm{C}$. Diligent laboratory procedures were applied to minimize environmental contamination. Positive (USG3 DNA), negative (E. chaffeensis DNA), and water controls were included in each assay. Ten microliters of each PCR product was added to sample wells of gels containing $1 \%$ agarose in $0.04 \mathrm{M}$ Tris-acetate-0.01 M EDTA (TAE) buffer, $\mathrm{pH} 8.4$, and gel electrophoresis was conducted for $1 \mathrm{~h}$ at $125 \mathrm{~V}$ in TAE buffer. The ethidium bromide-stained gels were photographed under shortwave UV (300-nm) illumination.

The presence of inhibitors to the PCR was assessed by adding positive control DNA from the HGE agent (USG3 isolate) to negative samples and retesting them in the assay. When inhibition was noted, we tested a dilution series of USG3 DNA that was spiked with several dilutions of pooled rodent DNA. The USG3 dilution series was carried out until the ehrlichial DNA could no longer be detected. The relative level of detection of ehrlichial DNA diluted in Tris saline buffer was compared to the relative level of detection in series that had been spiked with rodent DNA. The results of these experiments were used to determine the minimum dilution of rodent sample necessary to eliminate noticeable inhibition of the PCR. The rodent samples were again tested after diluting them $1 / 20$ in Tris saline buffer.

\section{RESULTS}

Occurrence of HGE antibodies in rodent serum and blood samples. None of the 16 serum samples from laboratoryreared $P$. leucopus mice reacted with the USG3 antigen at a $1 / 16$ dilution, and a pool of three sera was aliquoted for use as test controls. The positive control sample had an end point titer of 512 and gave a reaction pattern similar to that seen for sera from HGE cases (22). The overall amount of nonspecific binding of the rodent samples to the HL-60 cells was less than the very low level observed in most human sera. No difference in reactivity or background fluorescence among serum, plasma, and blood samples was noted.

Of the 1,240 specimens from wild rodents assayed, $136(11 \%)$ had antibodies reactive with the HGE agent at the screening dilution of 1/32 (Table 1). None of the 178 mice collected in Florida, Maryland, New Jersey, North Carolina, and Wisconsin had antibodies that were reactive against $E$. chaffeensis antigen, suggesting that this reactivity was not due to cross-reaction with E. chaffeensis.

Genus Peromyscus. Of the 1,095 rodents of the genus Peromyscus tested, $131(12 \%)$ had antibodies reactive with the HGE agent (Table 1). Specific P. leucopus antibodies were found in mice collected in Connecticut (11 of 100), Maryland (1 of 15), New Jersey (1 of 23), New York (113 of 491), and Wisconsin (1 of 8 ), but not in mice collected in Colorado, Georgia, Illinois, North Carolina, or Ohio (Table 2). Other members of the genus found to have antibodies reactive with the HGE agent were $P$. gossypinus (2 of 26) in Florida and $P$. boylii (1 of 9) and P. maniculatus (1 of 17) in Colorado. 
TABLE 1. Rodent species tested for antibodies reactive to the HGE agent

\begin{tabular}{|c|c|c|c|c|}
\hline Species & $n$ & $\begin{array}{l}\% \text { of } \\
\text { total }\end{array}$ & $\begin{array}{l}\text { No. reactive } \\
(\%)^{a}\end{array}$ & Titer \\
\hline P. boylii & 10 & 0.9 & $1(10)$ & 256 \\
\hline P. eremicus & 1 & 0.1 & 0 & \\
\hline P. gossypinus & 27 & 2.5 & $2(7.4)$ & $362(256-512)^{b}$ \\
\hline P. leuсория & 838 & 76.5 & 127 (15.2) & $414(32-4,096)^{b}$ \\
\hline P. maniculatus & 211 & 19.3 & $1(0.5)$ & 256 \\
\hline Peromyscus spp. & 23 & 2.1 & 0 & \\
\hline Total & 1,095 & & $131(12)$ & $410(32-4,096)^{b}$ \\
\hline N. albigula & 72 & 55.4 & $1(1.4)$ & 32 \\
\hline$N$. cinerea & 2 & 1.5 & 0 & \\
\hline N. fallax & 1 & 0.8 & 0 & \\
\hline N. fuscipes & 23 & 17.7 & $2(8.7)$ & $256(128-512)^{b}$ \\
\hline N. lepida & 4 & 3.1 & $1(25)$ & 512 \\
\hline N. mexicana & 21 & 16.2 & $1(4.8)$ & 256 \\
\hline N. micropus & 7 & 5.4 & 0 & \\
\hline Total & 130 & & $5(3.8)$ & $194(32-512)^{b}$ \\
\hline Grand total & 1,240 & & $136(11)$ & \\
\hline
\end{tabular}

${ }^{a}$ IFA titer of $\geq 32$

${ }^{b}$ GMT (range) of seroreactive (IFA titer $\geq 32$ ) samples.

Genus Neotoma. Of the 130 rodents of the genus Neotoma tested, five (4\%) had antibodies reactive with the HGE agent (Table 1). All of the rodents of this genus tested were collected from California and Colorado. Seroreactive N. albigula (1 of 72 ) and $N$. mexicana ( 1 of 21) samples were found in Colorado, while reactive $N$. fuscipes ( 2 of 23 ) and $N$. lepida (1 of 4) samples were found in California (Table 2). No $N$. cinerea $(n=$ $2), N$. fallax $(n=1)$, or $N$. micropus $(n=7)$ samples were seroreactive.

Frequency distribution of antibody titers. End point titers in the seroreactive rodents ranged from 32 to 4,096, with a modal titer of 512 (Fig. 1). Overall, $58 \%$ of seroreactive samples had titers of $\geq 512$. Rodents from the genus Peromyscus had titers that ranged from 32 to 4,096 $(\mathrm{GMT}=410)$. P. leucopus was the only species with end point titers of $\geq 1,024$. Samples from rodents of the genus Neotoma had titers that ranged from 32 to $512($ GMT $=194)$.

Seroreactive samples were found from rodents collected in 1986, 1991, 1993, 1995, and 1996, indicating that infections due to HGE or HGE-like organisms were occurring in rodents for several years prior to the first recognition of human HGE cases. The earliest seroreactive sample in our material was acquired from a white-footed mouse, P. leucopus (titer of 2,048), collected in June 1986 from East Haddam, Conn.

Geographic distribution. The highest percentages of antibody-positive specimens were from the areas where both the putative reservoir and vector coexisted (Table 3). Of the 690 specimens tested from this region, $127(18 \%)$ reacted to the HGE agent at titers ranging from 32 to 4,096. The largest proportion $(40 \%)$ of the samples from this region was collected in New York, and $113(83 \%)$ of the total of 136 seroreactive samples were identified from this state. Seroreactive $P$. leucopus mice were also found in Connecticut, New Jersey, and Wisconsin, states where HGE is known to occur.

In the region where the putative vector was common or present but where $P$. leucopus noveboracensis was uncommon or absent, only $2(2 \%)$ of 95 rodent samples were seroreactive to the HGE agent. Two P. gossypinus samples from Florida had titers of 256 and 512, and both of the rodents were caught in Dade County. No seroreactive animal was found in the region where the expected vector was uncommon or absent and the expected rodent reservoir was present.

In the region where both the putative vector and putative reservoir were absent, $7(2 \%)$ of 371 sera from six different species reacted with the HGE antigen. Three (9\%) of 32 California Neotoma samples and 4 (1.9\%) of 212 Colorado woodrat and Peromyscus sp. samples possessed antibodies to the HGE agent. Two of the three positive woodrat samples from California, from $N$. fuscipes and N. lepida, were obtained in San Diego County, and both had titers of 512. The third sample was from an $N$. fuscipes woodrat from urban Los Angeles County and had a titer of 128 . The four seroreactive rodent samples from Colorado were collected from widely separated counties and habitats: seroreactive $N$. mexicana and $P$. boylii animals originated from the grasslands of southern Las Animas County; one P. maniculatus mouse came from Hesperus Mountain

TABLE 2. Geographic distribution of rodents tested for antibodies reactive to the $\mathrm{HGE}$ agent

\begin{tabular}{|c|c|c|c|c|}
\hline State & Species & $n$ & $\begin{array}{c}\% \text { of state } \\
\text { total }\end{array}$ & $\begin{array}{l}\text { No. reactive } \\
\qquad \%)^{a}\end{array}$ \\
\hline \multirow[t]{7}{*}{ California } & N. fallax & 1 & 3.1 & 0 \\
\hline & N. fuscipes & 23 & 71.9 & $2(8.7)$ \\
\hline & N. lepida & 4 & 12.5 & $1(25)$ \\
\hline & P. boylii & 1 & 3.1 & 0 \\
\hline & P. eremicus & 1 & 3.1 & 0 \\
\hline & P. maniculatus & 2 & 6.3 & 0 \\
\hline & Subtotal & 32 & & $3(9.4)$ \\
\hline \multirow[t]{8}{*}{ Colorado } & N. albigula & 72 & 33.9 & $1(1.4)$ \\
\hline & $N$. cinerea & 2 & 0.9 & 0 \\
\hline & N. mexicana & 21 & 9.9 & $1(4.8)$ \\
\hline & N. micropus & 7 & 3.3 & 0 \\
\hline & P. boylii & 9 & 4.2 & $1(11.1)$ \\
\hline & P. leисориs & 84 & 39.6 & 0 \\
\hline & P. maniculatus & 17 & 8 & $1(5.9)$ \\
\hline & Subtotal & 212 & & $4(1.9)$ \\
\hline \multirow[t]{2}{*}{ Connecticut } & Р. lеисория & 100 & 100 & $11(11.0)$ \\
\hline & Subtotal & 100 & & $11(11.0)$ \\
\hline \multirow{2}{*}{ Florida } & P. gossypinus & 27 & 100 & $2(7.4)$ \\
\hline & Subtotal & 27 & & $2(7.4)$ \\
\hline \multirow[t]{3}{*}{ Georgia } & P. leисориs & 14 & 87.5 & 0 \\
\hline & Peromyscus spp. & 2 & 12.5 & 0 \\
\hline & Subtotal & 16 & & 0 \\
\hline \multirow[t]{4}{*}{ Illinois } & P. leucopus & 15 & 55.6 & 0 \\
\hline & P. maniculatus & 9 & 33.3 & 0 \\
\hline & Peromyscus spp. & 3 & 11.1 & 0 \\
\hline & Subtotal & 27 & & 0 \\
\hline \multirow[t]{2}{*}{ Maryland } & P. leисориs & 15 & 100 & $1(6.7)$ \\
\hline & Subtotal & 15 & & $1(6.7)$ \\
\hline \multirow[t]{2}{*}{ Nevada } & P. maniculatus & 27 & 100 & 0 \\
\hline & Subtotal & 27 & & 0 \\
\hline \multirow[t]{3}{*}{ New Jersey } & P. leисориs & 23 & 30.3 & $1(4.3)$ \\
\hline & P. maniculatus & 53 & 69.7 & 0 \\
\hline & Subtotal & 76 & & $1(1.3)$ \\
\hline \multirow[t]{2}{*}{ New York } & P. leисориs & 491 & 100 & $113(23.0)$ \\
\hline & Subtotal & 491 & & $113(23.0)$ \\
\hline \multirow[t]{2}{*}{ North Carolina } & P. leucopus & 52 & 100 & 0 \\
\hline & Subtotal & 52 & & 0 \\
\hline \multirow[t]{4}{*}{ Ohio } & P. leисориs & 36 & 63.2 & 0 \\
\hline & P. maniculatus & 3 & 5.3 & 0 \\
\hline & Peromyscus spp. & 18 & 31.6 & 0 \\
\hline & Subtotal & 57 & & 0 \\
\hline \multirow[t]{2}{*}{ Utah } & P. maniculatus & 100 & 100 & 0 \\
\hline & Subtotal & 100 & & 0 \\
\hline \multirow[t]{2}{*}{ Wisconsin } & P. leucopus & 8 & 100 & $1(12.5)$ \\
\hline & Subtotal & 8 & & $1(12.5)$ \\
\hline Total of all states & & 1,240 & & $136(11.0)$ \\
\hline
\end{tabular}

${ }^{a}$ IFA titer of $\geq 32$. 


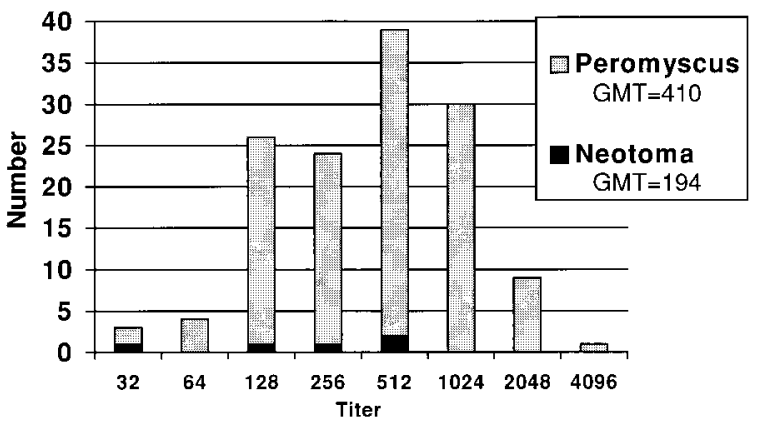

FIG. 1. Frequencies of antibody titers to the USG3 antigen in Peromyscus mice $(n=131)$ and Neotoma woodrats $(n=5)$ by IFA.

located in Montezuma County in southwestern Colorado; and one $N$. albigula woodrat came from the more mountainous region of Larimer County in north central Colorado. The sample from the last animal had a low titer ( 32 by IFA), whereas samples from the other Colorado rodents had titers of 256.

PCR assays. Tissues and blood from both seropositive and seronegative rodents were limited in availability. Forty organ tissue or whole-blood samples from rodents in Colorado, Florida, Maryland, New Jersey, and Wisconsin were extracted, and the DNA was tested by PCR assays. No bands of the expected size (919 bp) were amplified from the tissues by using the $16 \mathrm{~S}$ rRNA primers GE9 and GE10 in a one-step PCR, or with GE9 and GE10 after EC9 and EC12 in the nested PCR. Samples were tested twice in each assay. Upon further investigation, we found that many of the DNA samples were inhibitory to the PCR. Because excess rodent DNA might be the cause of the inhibition, we spiked a dilution series of DNA from the HGE agent with a series of dilutions of our rodent DNA. We determined that dilution of the samples $1 / 20$ in Tris saline buffer was sufficient to reduce the inhibition to a undetectable level. Thus, all samples were again assayed as before, with the rodent DNA samples at 1/20 dilutions. No tissue was found to be positive after the inhibition was removed.

\section{DISCUSSION}

This study provides additional evidence implicating whitefooted mice in a transmission cycle of HGE whereby I. scapularis ticks transmit the agents to humans. Other mammals may be shown to play a role, but our efforts largely focused on two genera of rodents. The majority of our seroreactive animals and the highest prevalences of antibodies were observed in locations where this tick and P. leucopus were common. In addition, this study provides the first evidence that the HGE agent or other HGE-like agents are widely distributed throughout the United States. It also provides the first evidence that HGElike agents may be associated with the genus Neotoma in the western United States.

We hypothesized that if the HGE agent was monotypic and had coevolved with specific hosts and vectors, then seroreactive mice would be limited to areas where the geographic ranges of the putative vector and putative reservoir host overlap. The expected enzootic cycle was defined as transmission among $P$. leucopus noveboracensis mice through the bites of I. scapularis ticks, as has been indicated by the known geographic range of HGE cases (29) and supported by preliminary observations $(23,27)$. Therefore, the estimated relative abundances of these two species in different geographic locations of the United States guided our selection of samples for this study.
For example, Wisconsin was chosen as a site where both the tick and the rodent subspecies coexist, while Utah was chosen as an area where neither is present. Although we recognize that HGE cases have been reported from additional areas where other hosts and vectors must be present, such as California, this sampling strategy would also identify areas where reservoir hosts and tick vectors for HGE or HGE-related organisms must be different from those in the hypothesized transmission cycle. In this initial survey, woodrats were selected for analysis where $P$. leucopus does not occur because extra-Peromyscus cycles of B. burgdorferi transmission that involve Neotoma spp. and their associated ticks have been found $(6,20)$.

The seroprevalence of antibodies to the HGE agent was highest among the rodents from states where HGE is known to infect humans, ticks, or other animals. Although our sample targeted the genus Peromyscus, specifically P. leucopus, we found three additional species ( $P$. maniculatus, $P$. gossypinus, and $P$. boylii) with antibodies reactive to the HGE agent. Previous studies have suggested that $P$. leucopus could be the principal reservoir host for the $\mathrm{HGE}$ agent in the northeast and upper Midwest $(27,30)$, and our data support this conclusion. We identified no seropositive $P$. leucopus mice outside of the known distribution of the northern subspecies, P. leucopus noveboracensis. However, our sample sizes were limited, and a lower prevalence of infection with the HGE agent cannot be excluded elsewhere in the geographic range of $P$. leucopus. If we assume an expected prevalence of $23 \%$, as was found in New York, then the probability of obtaining 10 negative animals and no reactors at any locality is 0.07 based on the binomial distribution. If the prevalence is actually lower, the power of our sampling efforts to detect a single reactive animal would be diminished and no conclusions can be drawn about the true geographic distribution of seroreactive animals.

The IFA used detects antibodies reactive with the E. phagocytophila genogroup (E. phagocytophila, E. equi, and the HGE

TABLE 3. Serologic test results grouped by state and by category of hypothesized vector and reservoir abundances

\begin{tabular}{|c|c|c|c|c|c|}
\hline $\begin{array}{c}\text { Category } \\
\text { (vector/re- } \\
\text { servoir) }\end{array}$ & State & $\begin{array}{l}\% \text { of } \\
\text { cate- } \\
\text { gory }\end{array}$ & $n(\%)$ & $\begin{array}{l}\text { No. } \\
\text { reactive }^{b} \\
(\%)\end{array}$ & Titer \\
\hline \multirow[t]{6}{*}{$\mathrm{CP} / \mathrm{CP}$} & Connecticut & 14.5 & 100 & $11(11.0)$ & $481(128-2,048)^{c}$ \\
\hline & New Jersey & 11.0 & 76 & $1(1.3)$ & 256 \\
\hline & New York & 71.2 & 491 & $113(23.0)$ & $419(32-4,096)^{c}$ \\
\hline & Maryland & 2.2 & 15 & $1(6.7)$ & 64 \\
\hline & Wisconsin & 1.1 & 8 & $1(12.5)$ & 128 \\
\hline & Total & & $690(55.6)$ & $127(18.4)$ & \\
\hline \multirow[t]{4}{*}{$\mathrm{CP} / \mathrm{UA}$} & Florida & 28.4 & 27 & $2(7.4)$ & $362(256-512)^{c}$ \\
\hline & Georgia & 16.8 & 16 & 0 & \\
\hline & North Carolina & 54.7 & 52 & 0 & \\
\hline & Total & & $95(7.7)$ & $2(2.1)$ & \\
\hline \multirow[t]{3}{*}{$\mathrm{UA} / \mathrm{CP}$} & Illinois & 32.1 & 27 & 0 & \\
\hline & Ohio & 67.9 & 57 & 0 & \\
\hline & Total & & $84(6.8)$ & $0(0.0)$ & \\
\hline \multirow[t]{5}{*}{ UA/UA } & California & 8.6 & 32 & $3(9.4)$ & $323(128-512)^{c}$ \\
\hline & Colorado & 57.1 & 212 & $4(1.9)$ & $256(32-256)^{c}$ \\
\hline & Nevada & 7.3 & 27 & 0 & \\
\hline & Utah & 27.0 & 100 & 0 & \\
\hline & Total & & $371(30.0)$ & $7(1.9)$ & \\
\hline
\end{tabular}

${ }^{a}$ Estimated relative abundances of $I$. scapularis and $P$. leucopus noveboracensis as hypothesized in the text. CP, common or present; UA, uncommon or absent. ${ }^{b}$ IFA titer of $\geq 32$.

${ }^{c}$ GMT (range) of reactive samples. 
agent). No significant detectable reactivity has been noted with sera containing antibodies to $E$. canis, E. risticii, E. sennetsu, or several rickettsial organisms (22). Although a limited number of human sera with increased levels of antibodies to $E$. chaffeensis can react with the antigen (22), rodents have never been found to have naturally occurring antibodies to E. chaffeensis (8a). Accordingly, all mice from our study collected in Florida, Maryland, New Jersey, North Carolina, and Wisconsin were nonreactive when tested with $E$. chaffeensis antigen in an IFA. Nevertheless, we cannot exclude infection by an as yet unidentified member of the E. phagocytophila genogroup.

The specific fluorescence observed indicated infection with organisms antigenically identical or closely related to the HGE agent. The GMT of the Peromyscus spp. (410) was greater than that of the Neotoma spp. (194), suggesting that ehrlichial agents associated with Neotoma species may be antigenically different from the HGE agent or that the immune response is reduced in woodrats. It should be noted that the number of seroreactive samples for the Neotoma woodrats was small. Also, the conjugate was produced against $P$. leucopus immunoglobulins and may have resulted in slightly lower titers with heterologous sera, although prior testing had shown this reagent to be useful in the detection of Peromyscus and Neotoma antibodies (10).

Our data suggest that high prevalences of host infection (up to $23 \%$ ) occur in certain geographic locations. GMTs of Peromyscus spp. from areas where HGE is endemic in the United States were greater than those from other regions of the country. However, this finding could also be due to the substantial contribution of $P$. leucopus from states where HGE is endemic to the overall sample. The majority of seroreactive P. leucopus mice were from New York and Connecticut, and they may have been infected with a strain of the HGE agent more similar to the isolate we used (originating from ticks in Pennsylvania and New York), thus resulting in higher titers to a homologous antigen.

The prevalence of specific antibodies to HGE or related organisms detected in wild rodents has ranged from about $10 \%$ in Minnesota (30) to only $1.8 \%$ in a marginal urban habitat of Maryland (7). Other investigators have also found a high prevalence of infection among the putative vector ticks that feed upon these hosts. Using a PCR assay, Pancholi and coworkers (23) found a single positive I. scapularis tick collected from a deer near Spooner, Wis., in 1982. In our study, we detected specific antibodies in a mouse collected from that vicinity. In a field collection of 15 P. leucopus mice on Nantucket Island, 5 mice were found to be capable of infecting laboratory-reared $I$. scapularis nymphs with the HGE agent, suggesting a minimum prevalence of $33 \%$ in the rodents (27). In the Connecticut towns of Bridgeport, East Haddam, and Lyme during the autumn of 1994 (19), the agent of HGE was detected by PCR assay in $50 \%$ of 118 adult I. scapularis ticks. In our study, the townships of East Haddam and Lyme were where two samples (titers of 2,048) were obtained in 1986 and 1990, respectively, consistent with an established mouse-Ehrlichia relationship.

In the United States, wild rodents have not previously been implicated in the epidemiology of any ehrlichial disease other than HGE, although they may serve as experimental hosts for several ehrlichiae. A monocytic species, Ehrlichia muris, was isolated from the spleen of a mouse (Eothenomys kageus) in Japan (17), but no human cases due to this agent have been identified. Granulocytic ehrlichiae have been discovered in a Gambian giant rat (Cricetomys gambianus) (15), and an agent morphologically similar to the HGE agent was discovered in meadow voles (Microtus pennsylvanicus) and P. leucopus mice from Nantucket, Mass. (28). This agent, designated "Cytoecetes microti," was readily passaged among these rodents and the desert mouse, Peromyscus eremicus.

The identification of numerous seroreactive species in the genera Peromyscus and Neotoma suggests that multiple enzootic cycles for maintaining granulocytic ehrlichiae exist and that alternative vertebrate hosts or tick vectors will be identified in geographic areas outside of the northeast and Midwest foci of HGE. Currently there are limited data to suggest that human infection or disease is present in many of these regions where other vertebrate hosts or vectors occur, but our understanding of the epidemiology of HGE is incomplete. Whether multiple ehrlichial species exist or whether a single species is being maintained in numerous rodent species warrants further study.

Some data suggest that alternative vertebrate host and vector maintenance cycles may be epidemiologically relevant to human ehrlichiosis, as Peromyscus species from Florida and Colorado were found to have specific antibodies. Serologic evidence suggests that human infection by an HGE-like agent has occurred in Florida (13), and P. leucopus does not occur there. In 1984, an E. equi-like agent was reported from northern Florida in a horse fed upon by two I. scapularis ticks at the time of diagnosis (4). The presence of seroreactive cotton mice (P. gossypinus) from this state deserves further attention. In Colorado, the findings from $P$. boylii and $P$. maniculatus are significant because, although no human HGE cases are known, equine ehrlichiosis has been recorded from that state (4).

Four species of Neotoma woodrats (N. albigula, N. fuscipes, $N$. lepida, and $N$. mexicana) were found to have evidence of exposure to HGE-like species in California and Colorado. Enzootic transmission cycles involving woodrats for the ticktransmitted human pathogen $B$. burgdorferi in areas outside the distributions of $P$. leucopus and I. scapularis have been described $(6,20)$. These additional cycles may persist enzootically with no human association, but can become epidemiologically important when "bridge vectors" enter the cycle. Bridge vectors can serve as secondary vectors of human pathogens by feeding on both the enzootic host and humans. In California, $B$. burgdorferi is maintained in an enzootic cycle involving Ixodes neotomae and its woodrat host, $N$. fuscipes (6). The spirochete can be transmitted to humans only when Ixodes pacificus enters these cycles and serves as the bridge to humans. Maupin et al. (20) discovered a similar cycle in Colorado involving the Mexican woodrat, $N$. mexicana, and the tick Ixodes spinipalpis (which may be conspecific with I. neotomae).

The finding of seroreactive woodrats from California raises the possibility that woodrats could be an undiscovered natural reservoir of the veterinary pathogen $E$. equi in the western United States. The taxonomic relationship between $E$. equi and the HGE agent is extremely close. The 16S rRNA gene sequences of $E$. equi from horses in the United States have only shown a 1- or 2-base difference from that of the HGE agent (1, 14), although Ehrlichia organisms from horses in Sweden have 16S rRNA gene sequences identical to that of the HGE agent (16). No reservoir host or vector for $E$. equi has been identified, but I. pacificus may experimentally transmit the organism among horses (25).

We were unable to amplify specific DNA of granulocytic ehrlichiae from any rodent tissue tested. Additional studies revealed that PCR inhibition was present in many of the wildrodent DNA samples. Dilution of the samples eliminated inhibition of the PCR as determined by spiking experiments, but this dilution might have affected our assay sensitivity. Unfortunately, only small quantities of whole blood or tissues were available for testing, thus limiting our ability to detect samples containing small amounts of ehrlichial DNA. Furthermore, we 
had a limited number of samples available for testing, and assays of additional samples may have increased our chances of detecting DNA from any HGE-like agent. Other studies have found a low prevalence of amplifiable ehrlichial DNA present in HGE antibody-positive mice (30). Further studies utilizing laboratory infections will be required to determine the optimal tissues for PCR testing, the timing of samples, and the relative levels of ehrlichial DNA in different rodent tissues. The inclusion of isolation attempts from wild rodents will be important in furthering our understanding of the relationships among these agents.

Human ehrlichiosis may continue to emerge as an important zoonosis in the United States as humans intrude upon enzootic cycles and as physician awareness of clinical human ehrlichiosis increases. As the clinical spectrum of the human ehrlichioses evolves and public health professionals become aware of the potential for maintenance cycles other than the P. leucopusI. scapularis cycle in the northeast, we may discover human disease due to granulocytic ehrlichiae in other regions of the United States.

\section{ACKNOWLEDGMENTS}

The antigen used in this study was provided by Aquila Biopharmaceuticals. We appreciate their continued support and cooperation. We thank T. Behr, T. G. Ksiazek, A. J. Williams, and J. N. Mills for facilitating access to the rodent samples. We also thank G. O. Maupin, M. Kosoy, M. Kennedy, and D. McKechnie for additional sera used in this work. Sergey Morzunov, S. T. Nichol, and S. Cantrell helped us remedy PCR inhibition in the rodent samples. The assistance of J. A. Comer in the organization and analysis of the data was invaluable. We appreciate the editorial assistance of J. O'Connor.

\section{REFERENCES}

1. Anderson, B. E., J. E. Dawson, D. C. Jones, and K. H. Wilson. 1991. Ehrlichia chaffeensis, a new species associated with human ehrlichiosis. J. Clin. Microbiol. 29:2838-2842.

2. Bakken, J. S., J. S. Dumler, S.-M. Chen, M. R. Eckman, L. L. van Etta, and D. H. Walker. 1994. Human granulocytic ehrlichiosis in the upper midwest United States: a new species emerging? JAMA 272:212-218.

3. Bakken, J. S., J. Krueth, R. L. Tilden, J. S. Dumler, and B. E. Kristiansen. 1996. Serological evidence of human granulocytic ehrlichiosis in Norway. Eur. J. Microbiol. Infect. Dis. 15:829-832.

4. Brewer, B. D., J. W. Harvey, I. G. Mayhew, and C. F. Simpson. 1984. Ehrlichiosis in a Florida horse. J. Am. Vet. Med. Assoc. 185:446-447.

5. Brouqui, P. H., J. S. Dumler, R. Lienhard, M. Brossard, and D. Raoult. 1995. Human granulocytic ehrlichiosis in Europe. Lancet 346:782-783.

6. Brown, R. N., and R. S. Lane. 1992. Lyme disease in California: a novel enzootic transmission cycle of Borrelia burgdorferi. Science 256:1439-1442.

7. Bunnell, J. E., J. S. Dumler, J. E. Childs, and G. E. Glass. Retrospective Peromyscus leucopus serosurvey for HGE in Baltimore, Maryland. Submitted for publication.

8. Centers for Disease Control and Prevention. 1995. Human granulocytic ehrlichiosis-New York, 1995. Morbid. Mortal. Weekly Rep. 44:593-595. (Errata, 44:653.)

8a.Centers for Disease Control and Prevention. Unpublished data.

9. Chen, S.-M., J. S. Dumler, J. S. Bakken, and D. H. Walker. 1994. Identification of a granulocytotropic Ehrlichia species as the etiologic agent of human disease. J. Clin. Microbiol. 32:589-595.

10. Childs, J. E., T. G. Ksiazek, C. F. Spiropoulous, J. W. Krebs, S. Morzunov, G. O. Maupin, K. L. Gage, P. E. Rollin, J. Sarisky, R. E. Enscore, J. K. Frey, C. J. Peters, and S. T. Nichol. 1994. Serologic and genetic identification of Peromyscus maniculatus as the primary rodent reservoir for a new hantavirus in the southwestern United States. J. Infect. Dis. 169:1271-1280.

11. Coughlin, R. T., C. Gingrich-Baker, T. Mather, and D. Fish. 1996. Trans- mission, isolation, and cultivation of granulocytic Ehrlichia resulting from infection of dogs by adult Ixodes scapularis collected from eastern United States, abstr. 52. In Abstracts of the 12th Sesquiannual Meeting of the American Society for Rickettsiology and Rickettsial Diseases. American Society for Rickettsiology, Albany, N.Y.

12. Dumler, J. S., K. M. Asanovich, J. S. Bakken, P. Richter, R. Kimsey, and J. E. Madigan. 1995. Serologic cross-reactions among Ehrlichia equi, Ehrlichia phagocytophila, and human granulocytic ehrlichia. J. Clin. Microbiol. 33:1098-1103.

13. Dumler, J. S., and J. S. Bakken. 1995. Ehrlichial diseases of humans: emerging tick-borne infections. Clin. Infect. Dis. 20:1102-1110.

14. Goodman, J. L., C. Nelson, B. Vitale, J. E. Madigan, J. S. Dumler, T. J. Kurtti, and U. G. Munderloh. 1996. Direct cultivation of the causative agent of human granulocytic ehrlichiosis. N. Engl. J. Med. 334:209-215.

15. Gretillat, S., X. Mattei, and B. Marchaud. 1981. Une rickettsiale nouvelle (Ehrlichiae) des leucocytes du sang du rat de Gambie (Cricetomys gambianus) au Senegal: Cytoecetes kamtchoulii n. sp. Rev. Elev. Med. Vet. Pays Trop. 34:391-396.

16. Johansson, K.-E., B. Pettersson, M. Uhlen, A. Gunnarsson, M. Malmqvist, and E. Olsson. 1995. Identification of the causative agent of granulocytic ehrlichiosis in Swedish dogs and horses by direct solid phase sequencing of PCR products from the 16S rRNA gene. Res. Vet. Sci. 58:109-112.

17. Kawahara, M., C. Suto, Y. Rikihisa, S. Yamamoto, and Y. Tsuboi. 1993. Characterization of ehrlichial organisms isolated from a wild mouse. J. Clin. Microbiol. 31:89-96.

18. Madigan, J. E., P. J. Richter, Jr., R. B. Kimsey, J. E. Barlough, J. S. Bakken, and J. S. Dumler. 1995. Transmission and passage in horses of the agent of human granulocytic ehrlichiosis. J. Infect. Dis. 172:1141-1144.

19. Magnarelli, L. A., K. C. Stafford III, T. N. Mather, M.-T. Yeh, K. D. Horn, and J. S. Dumler. 1995. Hemocytic rickettsia-like organisms in ticks: serologic reactivity with antisera to ehrlichiae and detection of DNA of agent of human granulocytic ehrlichiosis by PCR. J. Clin. Microbiol. 33:2710-2714.

20. Maupin, G. O., K. L. Gage, J. Piesman, J. Montenieri, S. L. Sviat, L. VanderZanden, C. M. Happ, M. Dolan, and B. J. B. Johnson. 1994. Discovery of an enzootic cycle of Borrelia burgdorferi in Neotoma mexicana and Ixodes spinipalpis from northern Colorado, an area where Lyme disease is nonendemic. J. Infect. Dis. 170:636-643.

21. Munderloh, U. G., J. E. Madigan, J. S. Dumler, J. L. Goodman, S. F. Hayes, J. E. Barlough, C. M. Nelson, and T. J. Kurtti. 1996. Isolation of the equine granulocytic ehrlichiosis agent, Ehrlichia equi, in tick cell culture. J. Clin. Microbiol. 34:664-670.

22. Nicholson, W. L., J. A. Comer, J. W. Sumner, C. Gingrich-Baker, R. T. Coughlin, L. A. Magnarelli, J. G. Olson, and J. E. Childs. 1997. An indirect immunofluorescence assay using a cell culture-derived antigen for detection of antibodies to the agent of human granulocytic ehrlichiosis. J. Clin. Microbiol. 35:1510-1516.

23. Pancholi, P., C. P. Kolbert, P. D. Mitchell, K. D. Reed, J. S. Dumler, J. S. Bakken, S. R. Telford, and D. H. Persing. 1995. Ixodes dammini as a potential vector of human granulocytic ehrlichiosis. J. Infect. Dis. 172:1007-1012.

24. Perez, M., Y. Rikihisa, and B. Wen. 1996. Ehrlichia canis-like agent isolated from a man in Venezuela: antigenic and genetic characterization. J. Clin. Microbiol. 34:2133-2139.

25. Richter, P. J., Jr., R. B. Kimsey, J. E. Madigan, J. E. Barlough, J. S. Dumler, and D. L. Brooks. 1996. Lxodes pacificus (Acari:Ixodidae) as a vector of Ehrlichia equi (Rickettsiales: Ehrlichieae). J. Med. Entomol. 33:2-5.

26. Sumption, K. J., D. J. M. Wright, S. J. Cutler, and B. A. S. Dale. 1995. Human ehrlichiosis in the UK. Lancet 346:1487-1488.

27. Telford, S. R., III, J. E. Dawson, P. Katavolos, C. K. Warner, C. P. Kolbert, and D. H. Persing. 1996. Perpetuation of the agent of human granulocytic ehrlichiosis in a deer tick-rodent cycle. Proc. Natl. Acad. Sci. USA 93:62096214.

28. Tyzzer, E. E. 1938. "Cytoecetes microti” n. g., n. sp., a parasite developing in granulocytes and infective for small rodents. Parasitology 30:242-257.

29. Walker, D. H., and J. S. Dumler. 1996. Emergence of the ehrlichioses as human health problems. Emerg. Infect. Dis. 2:18-29.

30. Walls, J. J., B. Greig, D. F. Neitzel, and J. S. Dumler. 1997. Natural infection of small mammal species in Minnesota with the agent of human granulocytic ehrlichiosis. J. Clin. Microbiol. 35:853-855.

31. Yeh, M.-T., T. N. Mather, R. T. Coughlin, C. Gingrich-Baker, J. W. Sumner, and R. F. Massung. 1997. Serologic and molecular detection of granulocytic ehrlichiosis in Rhode Island. J. Clin. Microbiol. 35:944-947. 